\title{
Mugilid Fish Are Sentinels of Exposure to Endocrine Disrupting Compounds in Coastal and Estuarine Environments
}

\author{
Maren Ortiz-Zarragoitia, Cristina Bizarro, Iratxe Rojo-Bartolomé, Oihane Diaz de Cerio, \\ Miren P. Cajaraville and Ibon Cancio* \\ Research Centre for Experimental Marine Biology and Biotechnology, Plentzia Marine Station \\ (PIE-UPV/EHU) and Department of Zoology and Animal Cell Biology, Faculty of Science and \\ Technology, University of the Basque Country (UPV/EHU), E-48080 Bilbao PO Box 644, \\ Basque Country, Spain; E-Mails: maren.ortiz@ehu.es (M.O.-Z.); cristina.bizarro@ehu.es (C.B.); \\ iratxe.rojo@ehu.es (I.R.-B.); oihane.diazdecerio@ehu.es (O.D.C.); \\ mirenp.cajaraville@ehu.es (M.P.C.)
}

* Author to whom correspondence should be addressed; E-Mail: ibon.cancio@ehu.es; Tel.: +34-946012734; Fax: +34-946013500.

Received: 1 April 2014; in revised form: 11 August 2014 / Accepted: 27 August 2014 / Published: 12 September 2014

\begin{abstract}
Effects on fish reproduction can result from a variety of toxicity mechanisms first operating at the molecular level. Notably, the presence in the environment of some compounds termed endocrine disrupting chemicals (EDCs) can cause adverse effects on reproduction by interfering with the endocrine system. In some cases, exposure to EDCs leads to the animal feminization and male fish may develop oocytes in testis (intersex condition). Mugilid fish are well suited sentinel organisms to study the effects of reproductive EDCs in the monitoring of estuarine/marine environments. Up-regulation of aromatases and vitellogenins in males and juveniles and the presence of intersex individuals have been described in a wide array of mullet species worldwide. There is a need to develop new molecular markers to identify early feminization responses and intersex condition in fish populations, studying mechanisms that regulate gonad differentiation under exposure to xenoestrogens. Interestingly, an electrophoresis of gonad RNA, shows a strong expression of 5S rRNA in oocytes, indicating the potential of 5S rRNA and its regulating proteins to become useful molecular makers of oocyte presence in testis. Therefore, the use of these oocyte markers to sex and identify intersex mullets could constitute powerful molecular biomarkers to assess xenoestrogenicity in field conditions.
\end{abstract}


Keywords: mullets; endocrine disrupting chemicals; xenoestrogenicity; intersex; molecular markers; 5S rRNA; TFIIIA; environmental monitoring

\section{Introduction}

Complex contaminant cocktails arrive at estuarine and coastal areas affecting the health of the organisms inhabiting these special ecosystems. Effects are not exclusive to littoral areas, organisms from offshore and deep sea zones have also been impacted by anthropogenic pollutants [1,2]. Among contaminant families detected in the marine environment, the presence of endocrine disrupting chemicals (EDCs) has received special attention [3,4]. EDCs have been defined as exogenous substances or mixtures that alter functions of the endocrine system and consequently adversely affect the health of exposed organisms, (sub)populations, or their progeny [4-7].

Contaminants classified as reproductive EDCs include plasticizers, pesticides, fungicides, surfactants, dioxins, polychlorinated biphenyls, electrical transformers, and pharmaceuticals such as the synthetic estrogen $17 \alpha$-ethinylestradiol [8]. They can also be produced as breakdown products of other chemicals and some are natural occurring compounds, synthesized for instance by plants and fungi such as phyto-estrogens and myco-estrogens [9]. The effects of EDCs in aquatic organisms are well known, feminization of male and juvenile fish being one of the best described effects $[4,6,9,10]$. Male fish with testis containing oocytes (known as intersex condition) have been described in aquatic environments receiving feminizing EDCs or xenoestrogens. Intersex condition has been defined as the presence of oocytes, individually or in clusters, within testicular tissue [6,11-13]. In the most severe cases, completely feminized gonads have been described [11]. Fish individuals showing intersex condition have lower reproduction capacity than non-impacted ones, indicating a threat for population viability [13-15]. In extreme and long-lasting xenoestrogen exposure scenarios, collapse of fish populations has been described [16]. Nevertheless, a recent study in roach, Rutilus rutilus, populations from UK rivers, did not show any direct association between intersex condition and population dynamics [17].

Xenoestrogens can alter normal sexual differentiation and gametogenesis because they can interfere with synthesis, storage, release, transport, metabolism, binding action and/or elimination of endogenous hormones [4,9,18]. Levels of vitellogenin, the precursor molecule of egg-yolk proteins, have been extensively measured as biomarker of xenoestrogenicity in adult male and immature fish $[3,9,19]$. Vitellogenin is a phosphoglycolipoprotein that once synthesized in the liver is secreted into the blood and transported to the ovary, where it is sequestered to form yolk proteins in growing oocytes $[10,20]$. Genetically determined sex has only been demonstrated in a few fish species, but even in these species, steroid hormones, either exogenous or endogenous, play a crucial role in sexual differentiation [21,22]. Aromatases, belonging to the $\mathrm{P} 450$ cytochrome family of proteins, are responsible for the transformation of androgens into estrogens. They are key proteins in the control of steroid balance during sexual differentiation, development and reproduction [21,23]. Two different aromatase isoforms, encoded by two different genes, have been described in fish. They show distinct regulation mechanisms and tissue distribution; cyp19ala (ovarian aromatase) and cyp19alb (brain aromatase), both synthesizing estrogens 
from androgens [24-26]. Exposure to EDCs can modulate the activity of both aromatases and alter the transcription in target tissues [23,25,27,28].

Although in terms of number of species, effects of reproductive EDCs have been mainly reported in freshwater fish [11], marine organisms are also exposed to them. One of the pioneering and more complete surveys of xenoestrogenicity to marine fishes was performed in the 1990s in UK estuaries. Male flounder (Platichthys flesus) from industrialized estuaries showed elevated plasma levels of vitellogenin and intersex condition [29,30]. The authors demonstrated that feminized flounders were exposed to effluents from sewage treatment plants containing synthetic estrogenic pharmaceuticals (ethinylestradiol and diethylstilbestrol) and alkylphenols. Some male flounders with elevated vitellogenin concentrations were captured in the open sea, but these were hypothesized to be fish that had recently emigrated from a contaminated estuary [31]. Similar surveys were performed in estuarine and coastal areas of the Netherlands [32,33], USA [34,35], Japan [36,37] and recently in the South Bay of Biscay [38] demonstrating the worldwide extension of xenoestrogenic effects into the marine environment. The effects, however, are not restricted to estuarine and coastal areas, and several studies have reported feminizing effects offshore. Estrogenic effects have been observed in swordfish (Xiphias gladius) from the Mediterranean [39] and off the coast of South Africa [40], in tuna (Thunnus thynnus), little tuna (Euthynnus alletteratus) and red mullet (Mullus barbatus) from the Mediterranean Sea [41-43], and in elder male cod (Gadus morhua) and dab (Limanda limanda) from the Northeast Atlantic [44,45]. Teleost fish have been widely used as pollution sentinel organisms [46]. The aim of the present review is to provide an overview describing the potential of the family of mugilids as pollution sentinels. This family of teleosts is very well suited for the study of xenoestrogenic endocrine disruption in coastal ecosystems. We further want to review the functional significance of some novel, 5S rRNA related, molecular markers of intersex condition identified in thicklip grey mullets, Chelon labrosus, from polluted estuaries in the Basque coast.

\section{Mugilids as Sentinel Species of EDC Pollution}

The main characteristics established by Suter in 1993 [47] for a good sentinel species include: widespread distribution, high trophic status, ability to bio-accumulate pollutants, and easy to capture and maintain/study in captivity. It is advisable that they display a restricted home range, with a well-known biology and showing sensitivity but resilience to pollutant exposure. Mugilids are able to endure highly polluted environments, displaying several of the characteristics required for estuarine sentinel species [48-51]. Their worldwide distribution (Figure 1) and their similar life histories allow the comparison of responses in different geographical areas.

Mullets have been utilized in parasitological [52,53], phylogenic [54] and ecological studies [55] and in environmental health assessment [38,48,56-58]. Ferreira et al. [56] showed that the presence of pollutants induced oxidative stress responses in Mugil cephalus collected in the Douro estuary (Portugal). These mullets showed elevated levels of organochlorine compounds in their tissues [56]. Similar results were obtained in populations analyzed in toxaphene polluted environments in the USA [59]. Alterations of antioxidant enzyme activity levels and peroxisome proliferation were described in mullets collected in the polluted environment of the Arriluze marina located in the mouth of Bilbao estuary, South East Bay of Biscay [58]. All these studies and the UNEP-MEDPOL program, 
for the assessment of the health of the Mediterranean Sea, recommend the use of mugilids in biomonitoring studies as alternative to other species more difficult to capture [49].

Figure 1. World distribution map of different mugilid fish species showing their association to coastal waters and their wide distribution with the exception of (sub)-Arctic and (sub)-Antartic waters. The most widely distributed species is Mugil cephalus. The map illustrates the coexistence of different mullet species in many locations. Out of the four species shown, intersex condition has been described in M. cephalus, Chelon labrosus and Liza ramada. The map has been produced using the information available in Fishbase [60].

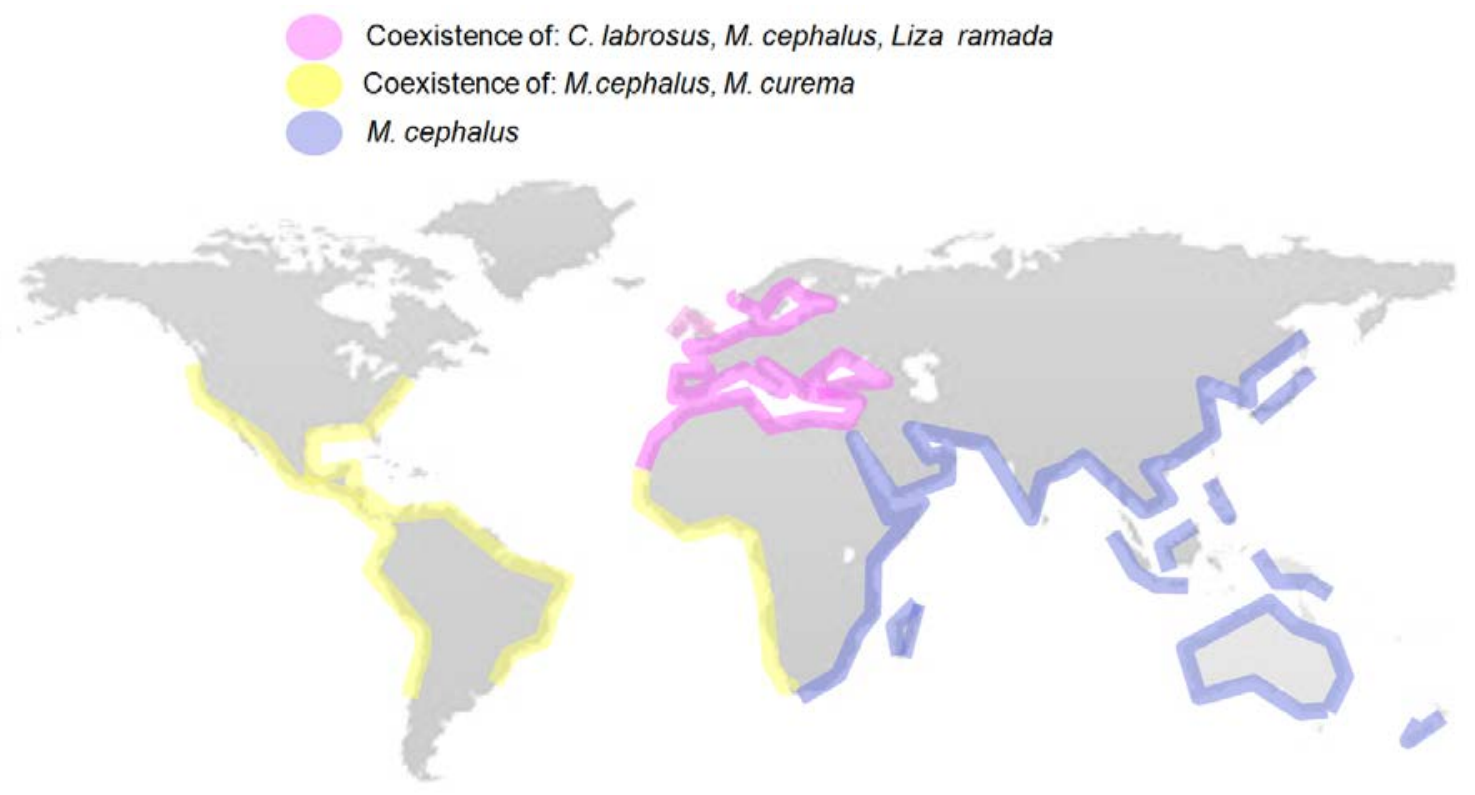

The family Mugilidae is formed by 20 genera, with 80 species, that are distributed worldwide (Supplementary Table S1), principally in seas of mild and tropical climates (Figure 1) [61,62]. All mullet species are pelagic and inhabit numerous habitats including coastal areas, estuaries, rivers, costal lagoons and seas. Mullets are considered gonochoristic but nonfunctional hermaphroditic characteristics have been associated to differentiated mature gonads in Mugil cephalus inhabiting coastal waters in South Carolina (USA) [63]. Sex differentiation, in M. cephalus and other mullets, begins after 12 months of age and the majority of immature fish at 15-17 months are differentiated sexually [63]. No chromosomal sexual determination system has been established, while environmental and polygenic factors have been suggested to play crucial roles in their sexual determination $[21,64]$. The sex ratio is 1:1 in most wild populations, but as the population ages a higher prevalence of females is found, probably due to a higher mortality of males [65]. Mullets are considered isochronal spawners; with synchronous gamete development. Individuals spawn all their gametes at once or in batches over a very short period of time [66-68].

Mugilids spawn in different periods of the year depending on the latitude and the species, but in all cases reproduction takes place offshore at sea [62,69,70]. After hatching, fry (young-of-the-year) are recruited into monospecific schools in protected coastal areas or in estuaries [70] and later return to littoral waters at ages that range, in the Mediterranean Sea, from 2 months in Chelon labrosus to 7 months in Liza ramada [69,71], at least. Unlike adults, all the Mugilidae larvae and post-larvae feed 
mostly on zooplankton; during the recruitment phase both larval (planktivorous) and adult (grazing/detritivorous) feeding strategies coexist in relative proportions, changing according to the food type available [71].

Due to its high ecological plasticity, Mugilidae is one of the dominant fish families in the ecosystems they inhabit [72-75]. The majority of Mugilidae species are highly euryhaline [76,77] and, being omnivorous, they are able to feed on a great variety of materials including detritus, unicellular algae, crustaceans, mollusks and insects $[76,78,79]$. This characteristic makes it an ecologically important family for its decisive contribution to the energy and matter flow from the lower to the upper levels in the ecosystems they inhabit [78-80]. Several different mugilid species can inhabit the same estuary (Figure 1), as they are able to utilize the food distributed from the thin water surface film to the bottom mud, either by direct grazing or using plant-detritus food chains as an energy source [71]. In fact, salinity gradients along coastal and estuarine environments also allow a zonal distribution of mugilids in a given system [81]. A day and night turnover of different mugilid species in estuaries has also been reported, supporting the co-habitation of several species in the same environment [82].

Mugilids have been widely farmed in aquaculture facilities, with selected target species depending on the region. The commercial importance of mugilids depends on the country and whether they are cultured for gathering roe or for food consumption [71,83]. The total world production of mullet species (fishery and aquaculture) is important and an increasing trend has been evidenced since 1950 [84].

Due to their benthic feeding strategy mullets tend to accumulate more contaminants than other fish species $[50,85,86]$. Thus, they are ideal organisms for the identification of the levels of metals $[49,50,87,88]$ or organic contaminants such as PCBs and organochlorine compounds [56,85,89] accumulated in tissues. Biological endpoints analyzed in mullets include pollution mediated skeletal deformities [90], oxidative stress and biotransformation enzyme responses [48,91], genotoxic responses [92,93] and endocrine disruption effects (see below). Information about key xenoestrogenicity biomarkers, such as vitellogenin and cyp19a1b aromatase is available for several mullet species. Specific antibody based ELISA tests have been developed for Mugil cephalus [94,95], Liza aurata [96] and Chelon labrosus [38] vitellogenin. The baseline level of plasma vitellogenin concentration in male $M$. cephalus from Korean and Japanese coastal waters has been established at $1 \mu \mathrm{g} / \mathrm{mL}$ [94]. Three different vitellogenins have been identified in M. cephalus, vitellogenins A, B and C which, as in other marine teleosts spawning pelagic eggs, are proteolytically-cleaved to different extents as maturation proceeds [97].

Although mullets can endure highly polluted environments, several works indicate that they may be more sensitive to EDC exposure than other fish species. Ferreira et al. [48] compared grey mullet (Mugil cephalus) and flounder (Plathychis flesus) inhabiting the Douro estuary (Portugal) and demonstrated that EROD activity levels in liver were 10 fold higher in mullets than in flounders. Furthermore, in the same study no intersex flounder was described but $21 \%$ of studied male mullets displayed intersex gonads. Juvenile so-iuy mullets (Mugil soiuy) injected with 17ß-estradiol (E2) were more sensitive to vitellogenin mRNA up-regulation than juvenile trout [98]. This higher sensitivity to xenoestrogens was recently corroborated in vitro at the molecular level, showing that so-iuy mullet estrogen receptor bound estrogenic hormones estradiol, estrone and estriol with higher affinity than medaka estrogen receptor [99]. 
Table 1. Summary of reports on endocrine disruption in wild populations of mullets. For a more comprehensive description of mentioned endpoints see the text (VTG = vitellogenin).

\begin{tabular}{|c|c|c|c|c|}
\hline Species & Common Name & Location & Xenoestrogenicity Endpoints Measured & References \\
\hline Chelon haematocheilus & Redlip mullet & East coast of China (East China Sea) & Intersex condition; VTG protein levels & [100] \\
\hline Chelon labrosus & Thicklip grey mullet & Basque coast (Bay of Biscay) & $\begin{array}{l}\text { Intersex condition; VTG protein and mRNA } \\
\text { levels; cyp19a1a and cyp19a1b aromatases } \\
\text { mRNA levels; oocyte molecular markers; } \\
\text { chemical metabolite levels in bile. }\end{array}$ & {$[38,101,102]$} \\
\hline Liza ramada & Thinlip grey mullet & Homa Lagoon (Izmir Bay-Aegean Sea) & Hermaphrodite (intersex) gonads & [103] \\
\hline \multirow{5}{*}{ Mugil cephalus } & \multirow{5}{*}{ Flathead grey mullet } & $\begin{array}{c}\text { Douro estuary } \\
\text { (Portugal, East Atlantic coast) }\end{array}$ & Intersex condition & {$[48,56]$} \\
\hline & & $\begin{array}{l}\text { Orbetello Lagoon-West } \\
\text { Italy (Mediterranean Sea) }\end{array}$ & $\begin{array}{l}\text { VTG mRNA levels; } \\
\text { oocyte development and atresia }\end{array}$ & [104-106] \\
\hline & & South coast of Korea (East China Sea) & Intersex condition; VTG protein levels & {$[94,100]$} \\
\hline & & South coast of Japan (East China Sea) & Intersex condition; VTG protein levels & {$[94,100]$} \\
\hline & & East coast of China (East China Sea) & Intersex condition; VTG protein levels & {$[100]$} \\
\hline Mugil soiuy & $\begin{array}{l}\text { So-iuy mullet/Far } \\
\text { Eastern mullet }\end{array}$ & North East coast of China (Bo Sea) & VTG mRNA levels & [98] \\
\hline
\end{tabular}




\section{Effects Mediated by EDCs in Mugilids}

The presence of ovotestis in mullets was described for the first time in the Ligurian Sea a century ago [107], but no potential causes were proposed. This fish, identified as Mugil chelo currently accepted name Chelon labrosus, contained ovarian lobes and testicular areas in the same gonad. Recent studies have reported the presence of intersex mullets in polluted estuaries worldwide (Table 1). Thus, intersex Liza ramada was described in waters polluted with industrial and agricultural outfalls in Turkey [103]. Intersex Mugil cephalus were found in estuaries from Korea, Japan, China and Portugal $[48,94,100]$. The testis of these fish showed dispersed previtellogenic or vitellogenic oocytes, suggesting exposure to xenoestrogenic compounds. Elevated vitellogenin levels, measured as plasma protein levels or liver mRNA transcript levels, were detected in male mullets from the same places where the intersex mullets had been collected. Similarly, in Mugil soiuy from Bo Sea (North China), polluted with urban and industrial effluent discharges, hepatic up-regulation of vitellogenin transcription was described [98].

Intersex gonads have also been described in Chelon labrosus (Figure 2) from estuaries in the South Bay of Biscay [38,101,102]. Oocytes have been found in male mullets from Bilbao, Pasaia and Ondarroa harbors, from the Deba river estuary and from the Biosphere Reserve of the Urdaibai estuary in Gernika [38,101]. Intersex mullets were found all along a reproductive annual cycle, with prevalences ranging from $3 \%$ to $60 \%$ of analyzed male mullets at each month [108]. Most C. labrosus showing intersex condition contained dispersed or small clusters of previtellogenic oocytes in testes (Figure 2) and were classified as presenting low to moderate intersex severity according to the index developed by Jobling et al. [109]. Elevated vitellogenin plasma and transcription levels were detected in these C. labrosus populations, accompanied by up-regulation of cyp19alb transcription levels in brain [101]. Furthermore, the detection of high levels of alkylphenols and synthetic estrogenic hormones, such as ethinylestradiol, in mullet bile demonstrated the exposure of these populations to xenoestrogenic compounds [38,101].

No statistical correlation was found between intersex condition and vitellogenin levels in mullet species [95,101]. Bahamonde et al. [11] suggested that additional mechanisms not directly estrogen dependent, should be involved in the development of intersex condition in fish. Other steroidogenic and neuroendocrine dependent pathways could be involved in the first steps of intersex gonad development. However, it is known that during puberty cyp19a1b expression in brain and cyp19ala in ovary increases in mullets, promoting female sexual differentiation in M. cephalus [110]. Similarly, Bizarro et al. [101] found that C. labrosus showing intersex condition had higher cyp 19alb transcription levels in brain than non-intersex males from the same population. Further work will help to elucidate the role played by aromatases and other steroidogenic genes and enzymes in the development of intersex condition in fish.

Anti-estrogenic effects have also been described in wild populations of mugilids. M. cephalus from the Orbetello Lagoon (West Italy), showing low brain acetylcholinesterase activity due to exposure to organophosphate and carbamate compounds, presented ovaries with underdeveloped and deformed oocytes [104]. Accordingly, no vitellogenin transcription was detected in the liver of these mullets $[105,106]$. 
Figure 2. Photomicrographs showing hematoxylin-eosin stained histological sections of thicklip grey mullet (Chelon labrosus) intersex gonads from South East Bay of Biscay; (a) Single previtellogenic oocyte (arrow) within testicular tissue at advanced gametogenic stage; (b) Presence of multiple previtellogenic oocytes (arrows) within testicular tissue at early gametogenic stage; (c) Vitellogenic oocytes (arrowheads) within testicular tissue at mature stage. Scale bars are $50 \mu \mathrm{m}$ (a), $100 \mu \mathrm{m}$ (b) and $200 \mu \mathrm{m}$ (c).
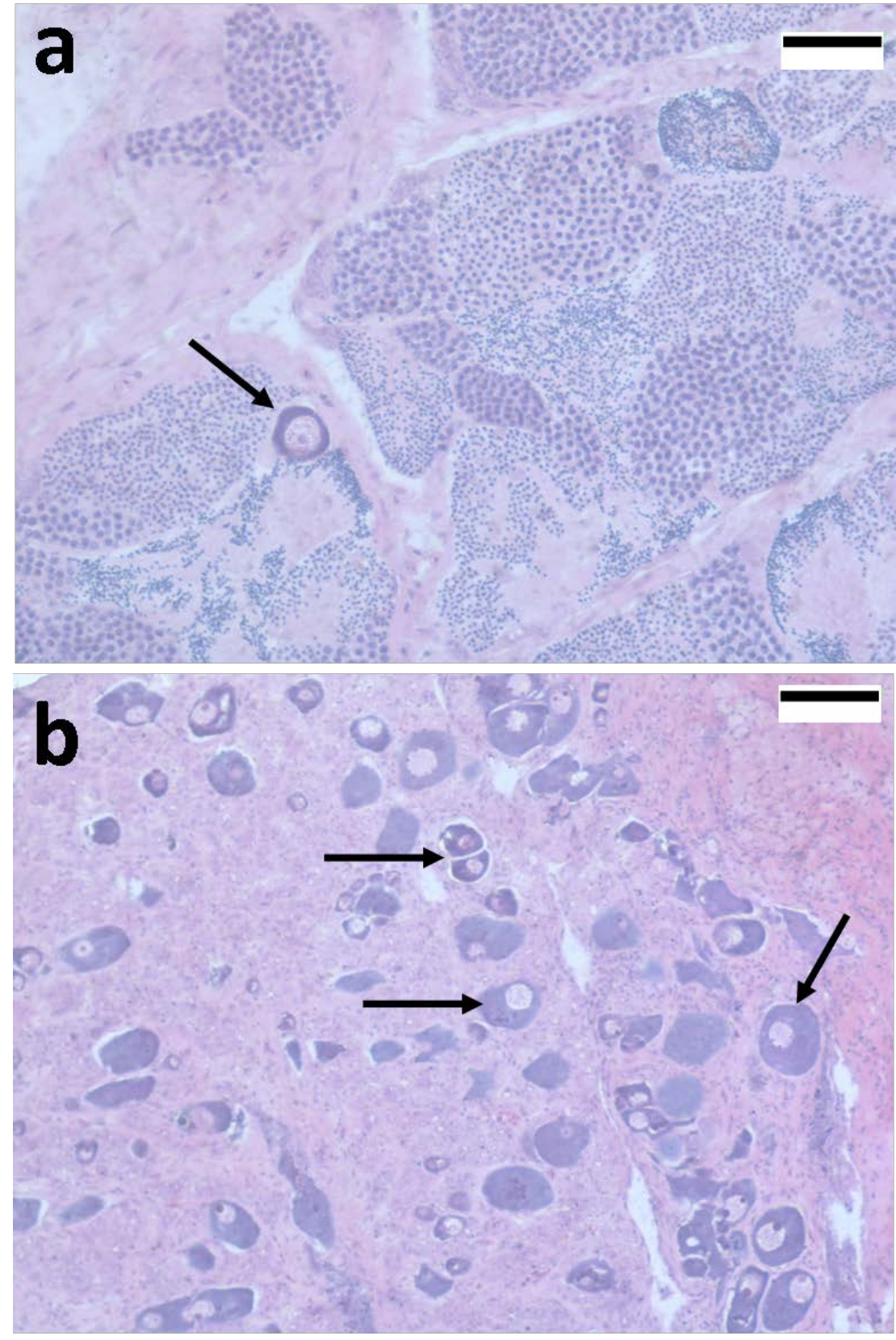
Figure 2. Cont.

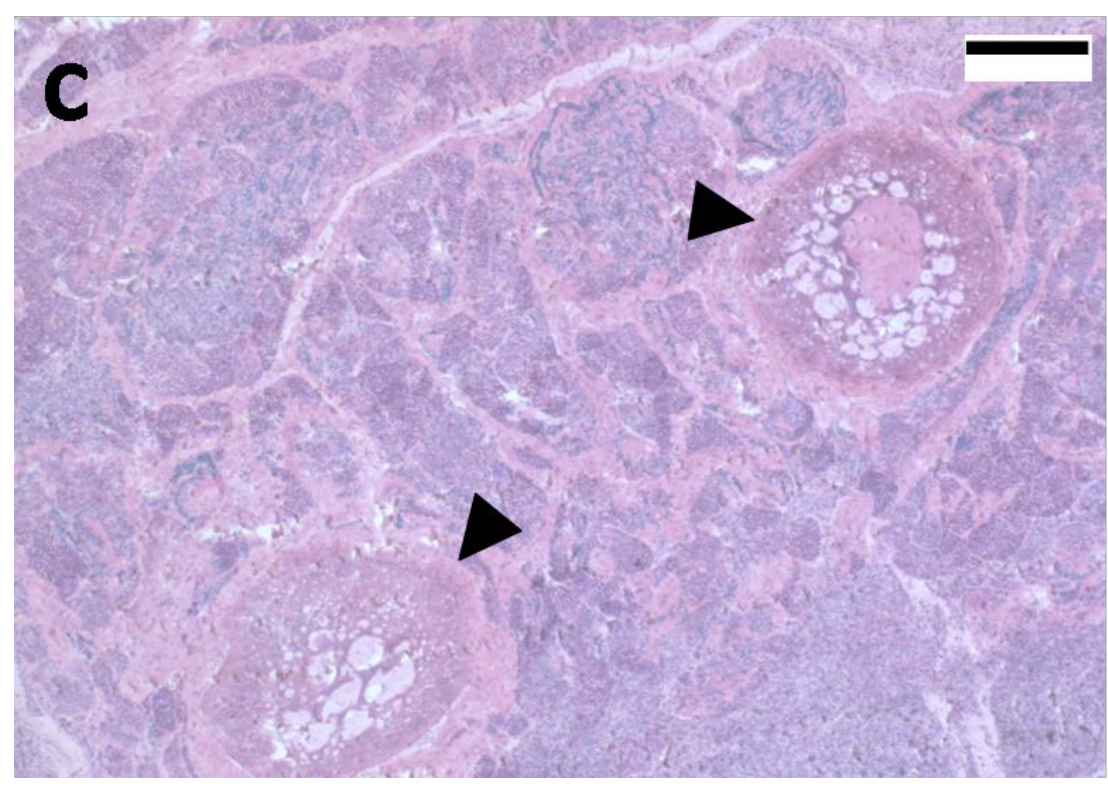

Mugilids are also suitable as experimental coastal fish to assess the action mechanisms and the effects of EDCs (Table 2). Several laboratory studies have focused on the effects of steroid hormones in the gametogenesis and sexual differentiation of mullets. Onset of oogenesis and induction of gonad aromatase activity have been demonstrated in juvenile $M$. cephalus after exposure to E2 during sexual differentiation [111]. Aoki et al. [112] accelerated oocyte differentiation and obtained complete feminization by feeding juvenile $M$. cephalus diets containing $4 \mu \mathrm{g} / \mathrm{g}$ ethinylestradiol (EE2). These hormonally treated mullets showed a parallel increase in plasma vitellogenin levels that was sustained even after having been placed in clean water for 149 days. Induction of aromatase activity in the gonads and complete feminization were also described in six month old juvenile mullets exposed to EE2 for four months [113]. These fish showed elevated plasma testosterone levels but no changes on estradiol levels were reported, although reduced levels of 11-ketotestosterone, the main active androgen in fish, were quantified after EE2 exposure [113]. On the other hand, exposure to $17 \alpha$-methyltestosterone induced complete masculinization, 11-ketotestosterone and testosterone plasma levels remaining high, while the majority of control animals at the age of 10 months, when the exposure experiment finished, remained undifferentiated [113]. Similarly, long-term exposure of juvenile $M$. cephalus to methyltestosterone through food, caused complete sex reversal when exposure took place 6-9 month after fertilization, the critical time for sexual differentiation [114]. Nevertheless, at sexual maturity (three years) some adult mullets were able to reverse the hormonally induced sex reversal [114]. Thus, exposure to EDCs affects sexual differentiation, and possibly intersex condition, depending on the time of exposure during mullet development. There is a sensitivity window along larval development, in which a transitory exposure to a low concentration of estrogenic EDCs can feminize male fish but after sex differentiation, the plasticity of fish gonads decreases. This window typically occurs during the first few months of larval development [21], a period spent offshore by mullet species. The late onset of sexual determination/differentiation in mugilids [21] thus, can coincide with the recruitment of fry (2-7 months, depending on the species) into estuarine waters, where they would be exposed to the large concentrations of chemicals typical of these highly anthropogenized environments. 
Table 2. Mullet exposure to endocrine disrupting chemicals under laboratory conditions. For a more comprehensive description of mentioned endpoints and responses see the text ( GSI = gonado-somatic index; VTG = vitellogenin).

\begin{tabular}{|c|c|c|c|c|}
\hline Species & Common Name & Treatment & Effect Endpoints Measured & References \\
\hline $\begin{array}{c}\text { Chelon } \\
\text { haematocheilus }\end{array}$ & Redlip mullet & $\begin{array}{l}\text { Nonylphenol }(0.01,0.1,1,10 \& 100 \mathrm{ng} / \mathrm{mL}) \\
\text { PCB126 }(0.01,0.1,1,10 \& 100 \mathrm{ng} / \mathrm{mL})\end{array}$ & Steroid levels in cultured oocytes & [115] \\
\hline Chelon labrosus & $\begin{array}{c}\text { Thicklip grey } \\
\text { mullet }\end{array}$ & $\begin{array}{c}\text { Perfluorooctane sulfonate (2 mg/L) } \\
\text { Heavy fuel oil (150 mL/11 kg sediment) }\end{array}$ & $\begin{array}{c}\text { VTG and cyp19a1b aromatase mRNA } \\
\text { levels }\end{array}$ & [116] \\
\hline Liza aurata & $\begin{array}{l}\text { Golden grey } \\
\text { mullet }\end{array}$ & $\begin{array}{c}\text { 17ß-estradiol }(2 \mu \mathrm{g} / \mathrm{L} \& 0.07 \mathrm{mg} / \mathrm{kg} \text { body weight }) \\
\text { Nonylphenol }(25,100,1000 \mu \mathrm{g} / \mathrm{L} \\
\& 0.25,250 \mathrm{mg} / \mathrm{kg} \text { body weight })\end{array}$ & VTG mRNA levels & [117] \\
\hline \multirow{8}{*}{ Mugil cephalus } & \multirow{8}{*}{$\begin{array}{l}\text { Flathead grey } \\
\text { mullet }\end{array}$} & $\begin{array}{c}\text { 17 } \beta \text {-estradiol }(1,8,15 \& 120 \mathrm{mg} / \mathrm{kg} \text { feed }) \\
17 \alpha \text {-ethinylestradiol (20 mg/kg feed) }\end{array}$ & $\begin{array}{c}\text { Oocyte development; GSI } \\
\begin{array}{c}\text { Gonad development; GSI; steroid plasma } \\
\text { levels; gonad aromatase activity. }\end{array}\end{array}$ & $\begin{array}{l}{[111]} \\
{[113]}\end{array}$ \\
\hline & & $17 \alpha$-ethinylestradiol ( $0.04 \& 4 \mu \mathrm{g} / \mathrm{kg}$ body weight) & Gonad development; VTG protein levels. & [112] \\
\hline & & $17 \alpha$-methyltestosterone (20 mg/kg feed) & $\begin{array}{l}\text { Gonad development; GSI; steroid plasma } \\
\text { levels; gonad aromatase activity. }\end{array}$ & [113] \\
\hline & & $17 \alpha$-methyltestosterone $(5,10 \& 15 \mathrm{mg} / \mathrm{kg}$ feed $)$ & Gonad development; VTG protein levels & [114] \\
\hline & & $17 \alpha$-methyltestosterone (4 mg/kg body weight) & \multirow{4}{*}{$\begin{array}{l}\text { Gonad development, steroid plasma levels, } \\
\text { VTG protein levels }\end{array}$} & \multirow[t]{4}{*}{ [118] } \\
\hline & & Domperidone ( $5 \mathrm{mg} / \mathrm{kg}$ body weight) & & \\
\hline & & GnRH (10 $\mu \mathrm{g} / \mathrm{kg}$ body weight) & & \\
\hline & & $\begin{array}{c}\text { Domperidone (5 mg/kg body weight) + } \\
\text { GnRH }(10 \mu \mathrm{g} / \mathrm{kg})\end{array}$ & & \\
\hline
\end{tabular}


Further to this and at the molecular level, it has been reported that the responses of mullets to EDCs are developmental and gametogenic stage specific. In juvenile L. aurata, waterborne exposure to E2 $(2 \mu \mathrm{g} / \mathrm{L})$ for one week did induce vitellogenin production, although hepatic down-regulation of cypla1 and inhibition of EROD activity were observed. However, adults intraperitoneally injected with $0.07 \mathrm{mg} / \mathrm{Kg}$ E2 showed elevated plasma levels and up-regulation of vitellogenin. Similar life history dependent opposite results were obtained when juvenile and adult $L$. aurata were exposed to nonylphenol [117]. In another study, exposure of Chelon haematocheilus vitellogenic oocytes in vitro to nonylphenol inhibited estradiol synthesis and stimulated testosterone production [115]. The authors suggested a potential anti-estrogenic effect of nonylphenol on mature oocytes $(0.75 \mu \mathrm{m})$, since exposure of pre-mature oocytes $(0.65-0.75 \mu \mathrm{m})$ did not elicit such response. No effects of PCB126 were detected in the same experimental model [117]. Oocyte development not only relies on estrogen levels, other neuroendocrine factors play an important role in the regulation of oogenesis. Aizen et al. [118] demonstrated that by inhibiting dopamine dependent response in adult $M$. cephalus, oocyte development and maturation were arrested. This suggests that mullet populations inhabiting waters polluted with dopamine antagonist drugs, such as domperidone, can show altered reproductive and gametogenic cycle. Transient responses to contaminants have been described in mullets that regulate their adaptive mechanisms and pathways which, in turn, might allow their survival in polluted environments. Juvenile $C$. labrosus exposed to perfluorooctanesulfonic acid and heavy fuel oil showed no changes of vitellogenin transcription levels but up-regulation of cyp19a1b and down-regulation of estrogen receptor alpha in the brain after two days of exposure were observed [116]. However, after 16 days of exposure no significant changes in the transcript levels of these genes were detected.

\section{Novel Intersex Markers in Mullets}

Sex determination results in the beginning of the differentiation process allowing bipotential primordial germ cells (PGCs) to produce either oocytes or sperm in the maturing fish. Female teleosts maintain germline stem cells for life, so they can produce an unlimited number of eggs during their reproductive lifetimes [119-121]. Timing of oocyte differentiation in females is controlled by estradiol and 11-ketotestosterone among other hormones. In each reproductive cycle PGCs transform into oogonia that initiate proliferation. When entering meiosis these oogonia render multiple primary oocytes, arrested in meiotic prophase [122]. Differentiation continues under hormonal control and as the oocyte grows, it accumulates cortical alveoli. These previtellogenic stage oocytes are also termed perinucleolar stage oocytes due to the proliferation of perinucleolar structures, structural manifestation of ribosomal RNA production. The development of the oocytes may be arrested at this stage until they are recruited for secondary growth, which results in massive growth during vitellogenesis, whereby the oocyte accumulates nutritional reserves, completing the differentiation of its cellular and non-cellular envelopes. If the oocyte recruitment stops before the spawning (mature egg) season then the species is considered to be a determinate fecundity species (synchronous, as in mugilids, gadoids, pleuronectoids or clupeids), while the recruitment continues until the postspawning period in the indeterminate fecundity species (anchovies, hakes, mackerels). In one case all oocytes display the same stage in the ovary (total spawners) as in mugilids, while in the others, oocytes in different maturation stages coexist in the ovaries (batch spawners) [123]. 
The term vitellogenesis describes the incorporation of hepatic vitellogenins into oocytes and their processing into yolk proteins [124]. Vitellogenin and egg envelope proteins are obviously oocyte markers, but only during vitellogenesis and not during the long period of the year in which oocytes remain in previtellogenic stage. This is also true for oocytes in intersex individuals, usually found in perinucleolar stage. Differentiation encompasses the whole process that allows the oocyte to become competent to undergo fertilization, through incorporation of maternal RNAs, proteins, lipids, carbohydrates, vitamins and hormones that are important for the proper development of the embryo. Each one of such molecules constitutes a marker of oocyte differentiation and in theory should constitute a marker of intersex condition in male fish producing oocytes in their testis. The high prevalence of intersex males in mullet populations inhabiting polluted estuaries in the Basque Country has provided opportunities of discovering such molecular markers of oocyte development in testis [101,102,108], which we need to understand functionally.

\subsection{S rRNA as a Sex Marker in Fish Gonads: A Crucial Molecule in Oocyte Differentiation}

A simple electrophoresis of total RNA extracted from gonads of thicklip grey mullets C. labrosus, is enough to identify their sex depending on the apparition or not of a potent low Mw band of 120 bp (Figure 3). This is so, irrespective of the moment along the reproductive cycle and site (polluted or not) of collection of samples. This band belongs to the smallest ribosomal RNA molecule, 5S rRNA [102]. In particular, 5S rRNA could constitute $75 \%$ of the total RNA content in a female gonad. Moreover, and as strong expression of 5S rRNA can be considered a marker of the presence of oocytes, intersex C. labrosus individuals from polluted estuaries can be identified due to their levels of 5S rRNA expression in between males and females [102]. It seems that oocytes need to accumulate 5S rRNA in order to quickly assemble ribosomes in case of being fertilized and sustain protein synthesis during embryogenesis.

Similar observations in the RNA profile of fish ovaries had been reported by Mazabraud et al. [125] and Denis and Wegnez [126] describing that in four out of nine teleost species studied tRNA and 5S rRNA made up more than $90 \%$ of the RNA content of the ovaries. Mittelholzer et al. [127] studying the gene transcription profiles of aromatase and 20 $\beta$-hydroxysteroid dehydrogenase in Atlantic cod ovary, described large peaks, of around 100 nucleotides in size, suggested by authors to belong to $5 \mathrm{~S}$ rRNA, that completely masked the normally predominant $18 \mathrm{~S}$ and $28 \mathrm{~S}$ rRNA peaks. The same description of small RNA molecules appearing on an electrophoresis of roach Rutilus rutilus ovarian total RNA was reported by Kroupova et al. [128]. In previtellogenic oocytes of teleosts, 5S rRNA is stored together with tRNA in ribonucleoprotein particles (RNPs) of different sizes [125].

Early vitellogenesis in amphibian oocytes is characterized by a dramatic increase in the expression of 5S rRNA genes whereas transcription is slowed down in later stages [129]. These variations in rRNA gene activity during oogenesis are accompanied by well-characterized ultrastructural modifications of the amphibian nucleolus. Fish also display a succession of transformations in nucleolar morphology during the differentiation of oogonia into mature oocytes, very similar to those in anurans [130]. The previtellogenic or perinucleolar oocytes are characterized by the richness in nucleoli [124]. 
Figure 3. (a) Typical electropherograms obtained from the electrophoretic analysis (Bioanalyzer 2000, Agilent Tech., Santa Clara, CA, USA) of total RNA extracted from the gonads of a female, a male and an intersex male thicklip grey mullets (C. labrosus). The 5S rRNA peak is clearly observed in ovary and in intersex testis, while the eukaryotic typical 18S and 28S rRNA peaks can be observed in testis; both normal and intersex. Note that the ovary shown belongs to a female in previtellogenic stage; (b) DNA electrophoresis showing the Q-PCR product obtained after specific amplification of TFIIIA cDNA from C. labrosus ovary (present) and testis (not present). The ghost band in testis is the result of primer dimmers.

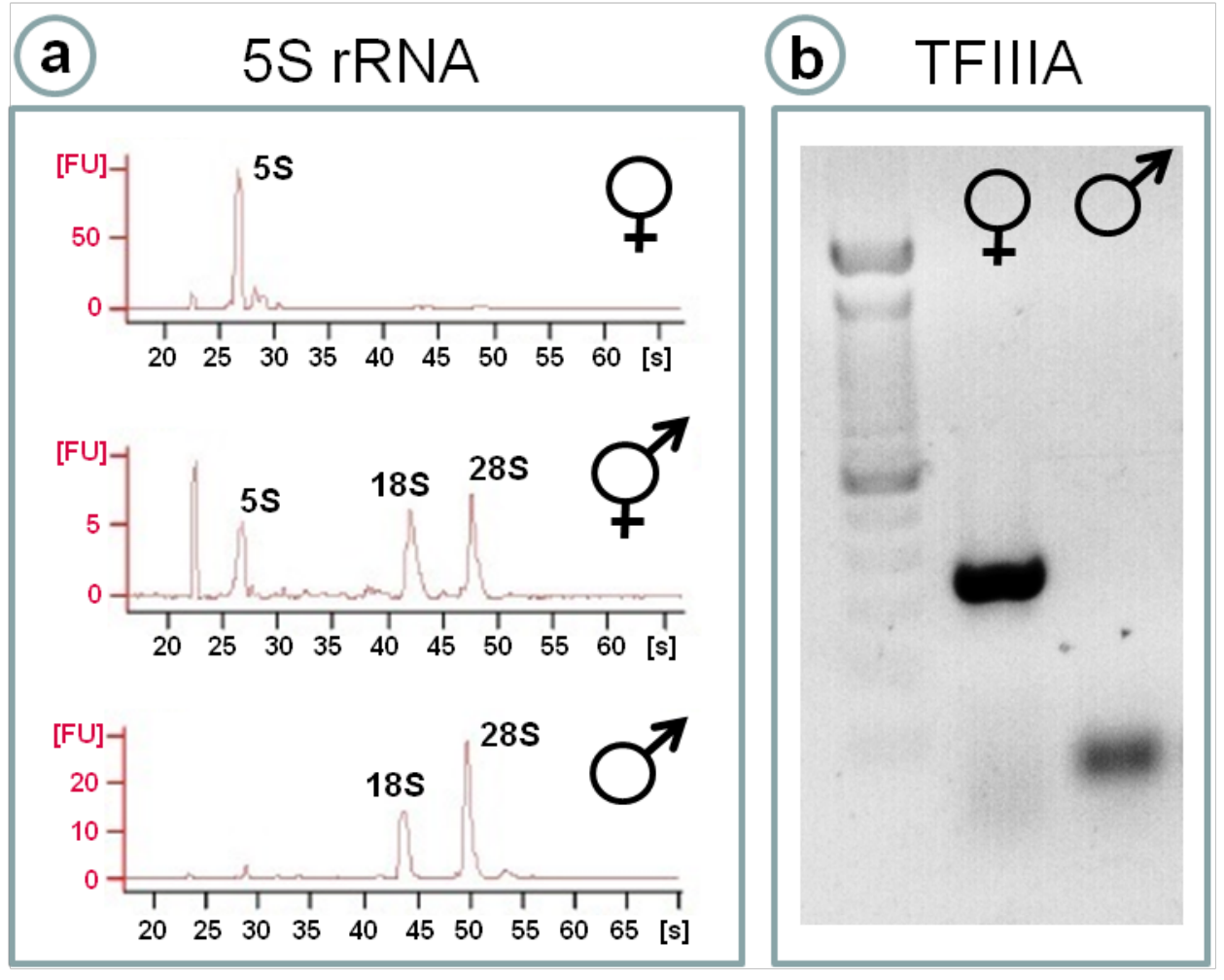

The 5S ribosomal RNA gene family is arranged in higher eukaryotes in several copies of tandem repeated units. Each unit consists of a highly conserved coding sequence of $120 \mathrm{bp}$, and a flanking non-transcribed spacer (NTS) [131-133]. This NTS has been employed as molecular marker for species identification [131,132]. Many studies have been published dealing with the structure, chromosomal location, and sequence variation of the 5S rRNA genes in fish, including grey mullets [131,132]. Two different types of 5S rDNA have been found in the frog Xenopus laevis, one expressed in somatic cells and the other in oocytes [134]. This system of two paralogous 5S rRNA gene classes is also common to fish species [126,131,135]. This has been assumed to reflect the existence of a gonadal and a somatic gene in fish, although the distinction so far has been restricted to describe the different 5S rDNA tandem repeats as organized in two distinct size-classes [131,135-137].

\subsection{Transcriptional Regulation of Ovarian $5 S$ rRNA and Storage of Ribosomal Subunits}

Q-PCR analysis of thicklip grey mullet demonstrated, for the first time in a fish species, that the transcriptional regulation of an ortholog of the general transcription factor IIIA (TFIIIA) resembled 
that of 5S rRNA in gonads. Intersex individuals showed transcription patterns in between both sexes [102], which makes TFIIIA also a potent molecular marker of oocytes. Interestingly, TFIIIA was also reported in a list of ovary-expressed genes in zebrafish [138].

Figure 4. Schematic representation of the processes and molecules involved in the transcription, nucleo-cytoplasmic transport and stockpiling of 5S rRNA in anuran and in fish oocytes (modified from [133]).

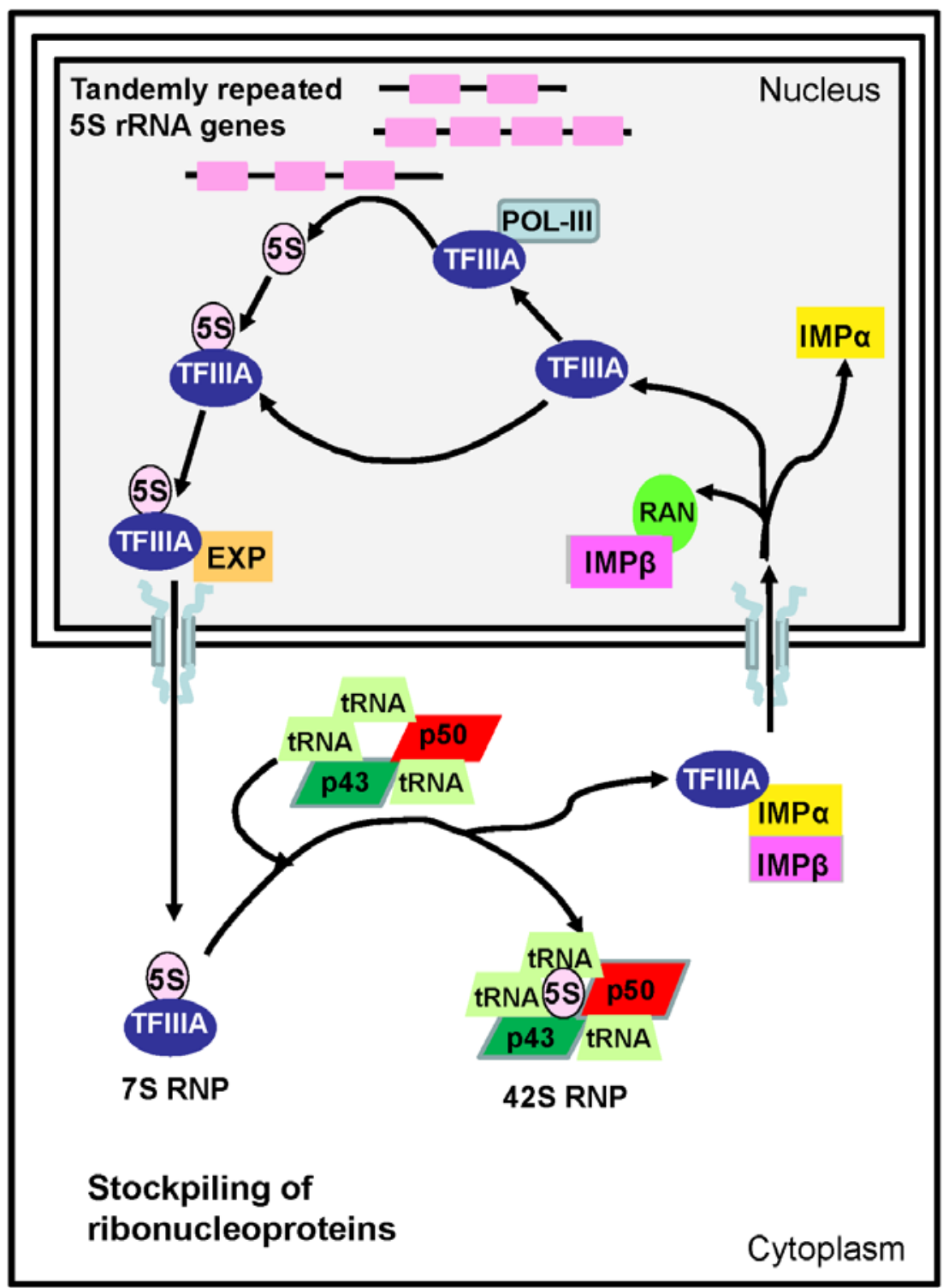

TFIIIA controls the transcription of 5S rRNA by RNA polymerase III in eukaryotes [133]. A single TFIIIA gene codes for two different isoforms, of 38 and $40 \mathrm{kDa}$ in Xenopus [139]. These isoforms correspond to the oocyte and somatic form of the protein, synthesized through differential promoter usage $[129,139]$. In Xenopus oocytes, TFIIIA forms a complex with 5S rRNA (7S RNP) that serves as a storage particle for 5S rRNA (Figure 4). Thus, TFIIIA specifically recognizes and binds the 5S rDNA promoter sequence, and also binds the resulting transcription product. Levels of TFIIIA mRNA mirror those of total 5S rRNA and, in Xenopus, are approximately one million times higher in oocytes than in somatic cells [129]. TFIIIA is overexpressed early in oogenesis (stages I-III), the protein 
constituting as much as $10 \%$ of the total cytoplasmic protein in anurans [129], and then decreases 5-10-fold by stage V-VI [139].

In fish, TFIIIA has only been characterized in the catfish, where it was shown to be associated to 5S rRNA in ovarian tissue [140]. Although the $38 \mathrm{kDa}$ protein only displays $40 \%$ aa sequence identity with Xenopus TFIIIA, it is able to bind Xenopus 5S rRNA genes. The possibility that two independent tfIIIa paralogous genes, one shorter than the other, exist in fish genomes can be suggested analyzing the fish genomes in ENSMBL (in zebrafish: gtf3aa ENSDARG00000030267, chromosome 5, protein size 367 aa and $42.6 \mathrm{kDa}$ and gtf3ab ENSDARG00000071583, chromosome 24, protein size 318 aa and $37.15 \mathrm{kDa}$ ). This opens the possibility to an ovarian specific TFIIIA gene, and an independent somatic gene, in teleost genomes.

Similarly to TFIIIA, mullet p43 or $42 \mathrm{sp} 43$ was transcribed to very high levels in ovaries of C. labrosus, during the entire reproductive cycle of females and in intersex males [102]. In addition to 7S RNP complexes, 5S rRNA is also stored in larger 42S RNPs (Figure 3). In Xenopus, approximately $50 \%$ of the 5S rRNA in oocytes is associated with TFIIIA, the other half being present in 42S RNPs. These RNPs consist of two proteins: 42sp50 (also termed p48) and 42sp43 (also termed p43 or thesaurin b). 42sp43 is a nine zinc-finger protein responsible for 5S rRNA binding, but unlike TFIIIA it is not able to bind the gene and it is not implicated in its transcriptional regulation [133]. The only reference in fish is about Oryzias latipes where both $42 s p 50$ and $42 s p 43$ gene transcripts were found to be ovary specific [141,142]. A transgenic medaka line constructed using a relative short upstream sequence and 3'UTR from the 42sp50 gene allowed oocytes to be fluorescently labeled; fluorescence beginning as early as five days after hatch [142]. Oocytes artificially induced in the testes of medaka were also fluorescently labeled [142].

\subsection{Nucleo-Cytoplasmic Transport of Proteins and Ribonucleoproteins during Oocyte Differentiation}

In eukaryotic cells, nucleo-cytoplasmic bidirectional transport of molecules relies on access through the nuclear pore complexes via carrier proteins, karyopherins [143]. They include members of the importin (IMP) and exportin (EXP) protein families. The best characterized mechanism of nuclear import is mediated by IMP $\alpha$ and IMP $\beta 1$ heterodimers (Figure 4). Nuclear proteins bind to IMP $\alpha$, and this complex is targeted by IMP $\beta 1$ to the nuclear pore. In this way, hundreds of different proteins can be specifically targeted into the nucleus. The IMP $\alpha$ gene family has expanded during evolution with a single gene in budding yeast, three in Drosophila melanogaster and Caenorhabditis elegans (impal to 3) and six IMP $\alpha$ genes in humans [143,144].

Little is known about this transport system in fish. An IMP $\alpha$, most similar to Xenopus IMP $\alpha 1$ and 2 and including an IMP $\beta$-binding domain, was characterized in the red seabream Pagrus major ovary [143]. RT-PCR analysis showed transcription of this P. major IMP $\alpha$ in testis, and especially in ovary, but not in other tissues. Three importin (impal and 2 and $i m p \beta 2)$ and four exportin (exp1, 5, 6 and 7) fragments have been cloned in C. labrosus and both impal and 2 followed the pattern of transcription of TFIIIA, constituting also potent sex and intersex (oocyte) markers [102].

A systematic analysis of IMP $\alpha$ variants in Xenopus (impal to 4, impa5.1 and 5.2) revealed that impal and 2 are transcribed in a pattern similar to tfIIIa during early oogenesis [145]. So TFIIIA could be imported into nuclei via interaction with these two proteins. A quick search of the different fish 
genomes available in ENSEMBL reveals 7 IMP $\alpha$ genes (termed kpnal to 7 for karyopherins), but it is not known how these other IMP $\alpha$ genes could be regulated during fish oogenesis and xenoestrogenicity causing intersex.

\subsection{How Is 5S rRNA Related Gene Expression Regulated in Fish Oocytes?}

Gene expression processes occurring during early oogenesis/spermatogenesis have to deal with DNA packaged under special structural circumstances while it is involved in the rearrangements occurring at meiosis. It has been reported that germ cells use alternate forms of core promoter transcription factors such as TBP, TAFs, and TFIIA [146]. Genes that encode variants of TFIIA, TBP, and TAFs have been discovered in male and female reproductive tissues [146] and have roles in spermatocytes, oocytes, and the early embryo. Some genes switch from a somatic promoter to one or more germ-cell-specific promoters. This is the case of tfIIIa gene in Xenopus [129] although we might be facing two separate genes in fish. The capacity to drive oocyte/sperm specific activation of tfIIIa transcription (under normal developmental and under exposure to EDCs causing intersex condition) and therefore 5S rRNA production seems central for oocyte differentiation in fish. A comparison of the germ cell specific promoters reveals that they all possess a small size (100 bp). This is exemplified by the transgenic $O$. latipes line [142] with fluorescent ovaries produced using the short promoter sequence of $42 s p 50$. It is not clear how such short promoters are able to specify germ cell activation and somatic silencing but they suggest that enhancer-dependent interactions are not required.

Certain regulatory factors, including Sp1, USF, NF-kB, CREM $\tau$, BORIS, SREBP2 or FIG $\alpha$ have been proposed to regulate genes in germ cells [146]. Sp1, USF and Vg1-RBP are known to bind the tfIIIa promoter region in Xenopus [128]. Activation of a tfIIIa control element, termed E3, is essential in specific gene transcription in Xenopus early oocytes. Gel shift assays have demonstrated that tfIIIa expression correlates with an E3 binding protein (termed the B3 activator and identified as Vg1-RBP) activity, with the highest levels in immature oocytes and very little in somatic cells [147]. Consequently Vg1-RBP may be an important stage specific transcriptional regulator of tfIIIa [147].

Questions that remain to be answered in mullets and in fish in general are:

- Which are the dynamics of activation of these oocyte markers during normal female sexual determination/differentiation?

- Which are the environmental (EDC exposure among them) and molecular clues, epigenetic mediators and pathways that regulate activation of 5S rRNA related genes so as to mask any other RNA production in PGCs that initiate differentiation into oogonia instead of spermatogonia?

- Could the levels of 5S rRNA accumulated into oocytes give information about the effects of EDCs on oogenesis and oocyte quality?

- Would these molecular markers function as intersex markers in other mugilid fish species, or in fish species with asynchronous gamete development? 


\section{Conclusions}

Within the mugilidae family of fish we find worldwide distributed and strategically placed euryhaline species that are very sensitive to exposure to xenoestrogenic compounds, both under natural and laboratory conditions. Although most mullet species reproduce in offshore marine waters, they return to littoral waters, mainly estuarine brackish waters, within 2-7 months after hatching. It would be then, coinciding with the period of juvenile sex differentiation, that they are first exposed to chemical pollutants in the water bodies receiving the chemicals coming from human settlements and activities. In this respect, intersex male individuals have been widely documented in different mullet species. Vitellogenins are the molecular markers traditionally used in monitoring of xenoestrogenic exposure, but they are not produced during the long lasting previtellogenic stages of oogenesis in most fish species. We need molecular markers able to identify mild intersex conditions all along the reproductive cycle. In this respect, and as it has been proved in intersex mullets captured in estuaries with high levels of EDCs, 5S rRNA and related proteins accumulated in all oocyte stages, could be such helpful markers.

\section{Acknowledgments}

This work has been funded through research projects of the Spanish MINECO (SEXOVUM AGL2012-33477), Basque Government (SAIOTEK OVUM-II S-PE12UN086 and Consolidated research groups IT-810-13) and UPV/EHU (UFI 11/37). IRB is recipient of a predoctoral grant of the Basque Government while CB is recipient of a grant of UPV/EHU.

\section{Conflicts of Interest}

The authors declare no conflict of interest.

\section{References}

1. Boehm, A.B.; Bischel, H.N. Oceans and Human Health. In Encyclopedia of Environmental Health; Nriagu, J., Ed.; Elsevier B.V.: Burlington, MA, USA, 2011; Volume 4, pp. 223-230.

2. DellaSala, D.A. Oceans and Global Change: One Blue Planet. Ref. Module Earth Syst. Environ. Sci. 2013, doi:10.1016/B978-0-12-409548-9.05878-4.

3. Matthiessen, P. Endocrine disruption in marine fish. Pure Appl. Chem. 2003, 75, 2249-2261.

4. WHO/UNEP (World Health Organization/United Nations Environment Programme). State-of-the-Science of Endocrine Disrupting Chemicals 2012; Bergman, A., Heindel, J.J., Jobling, S., Kidd, K.A., Zoeller, R.T., Eds.; WHO Press: Geneva, Switzerland, 2013. ISBN: 978-92-807-3274-0 (UNEP) and 978-92-4-150503-1 (WHO).

5. EEA (European Environmental Agency). Environmental Agreements: Environmental Effectiveness; Environmental Issue Report No. 3; European Environmental Agency: Copenhagen, Denmark, 1997; Volume 1-2.

6. Tyler, C.R.; Jobling, S. Roach, sex, and gender-bending chemicals: The feminization of wild fish in English Rivers. Bioscience 2008, 58, 1051-1059. 
7. Söffker, M.; Tyler, C.R. Endocrine disrupting chemicals and sexual behaviors in fish-A critical review on effects and possible consequences. Crit. Rev. Toxicol. 2012, 42, 653-668.

8. Tyler, C.R.; Jobling, S.; Sumpter, J.P. Endocrine disruption in wildlife: A critical review of the evidence. Crit. Rev. Toxicol. 1998, 28, 319-361.

9. Goksøyr, A.; Arukwe, A.; Larsson, J.; Cajaraville, M.P.; Hauser, L.; Nilsen, B.M.; Lowe, D.; Matthiessen, P. Molecular/cellular processes and the impact on reproduction. In Effects of Pollution on Fish; Lawrence, A.J., Hemingway, K.L., Eds.; Blackwell Science Ltd.: Oxford, UK, 2003; Chapter 5, pp. 179-220.

10. Goksøyr, A. Endocrine disruptors in the marine environment: Mechanisms of toxicity and their influence on reproductive processes in fish. J. Toxicol. Environ. Health Part A 2006, 69, 175-184.

11. Bahamonde, P.A.; Munkittrick, K.R.; Martyniuk, C.J. Intersex in teleost fish: Are we distinguishing endocrine disruption from natural phenomena? Gen. Comp. Endocrinol. 2013, 192, 25-35.

12. Bateman, K.S.; Stentiford, G.D.; Feist, S.W. A ranking system for the evaluation of intersex condition in European flounder (Platichthys flesus). Environ. Toxicol. Chem. 2004, 23, 2831-2836.

13. Jobling, S.; Williams, R.; Johnson, A.; Taylor, A.; Gross-Sorokin, M.; Nolan, M.; Tyler, C.R.; van Aerle, R.; Santos, E.; Brighty, G. Predicted exposures to steroid estrogens in U.K. rivers correlate with widespread sexual disruption in wild fish populations. Environ. Health Perspect. 2006, 114, 32-39.

14. Harris, C.; Hamilton, P.B.; Runnalls, T.J.; Vinciotti, V.; Henshaw, A.; Hodgson, D.; Coe, T.S.; Jobling, S.; Tyler, C.R.; Sumpter, J.P. The consequences of feminization in breeding groups of wild fish. Environ. Health Perspect. 2011, 119, 306-311.

15. Lange, A.; Paull, G.C.; Coe, T.S.; Katsu, Y.; Urushitani, H.; Iguchi, T.; Tyler, C.R. Sexual reprogramming and estrogenic sensitization in wild fish exposed to ethinylestradiol. Environ. Sci. Technol. 2009, 43, 1219-1225.

16. Kidd, K.; Blanchfield, P.J.; Mills, K.H.; Palace, V.P.; Evans, R.E.; Lazorchak, J.M.; Flick, R.W. Collapse of a fish population after exposure to a synthetic estrogen. Proc. Natl. Acad. Sci. USA 2007, 104, 8897-8901.

17. Hamilton, P.B.; Nicol, E.; de-Bastos, E.S.; Williams, R.J.; Sumpter, J.P.; Jobling, S.; Stevens, J.R.; Tyler, C.R. Populations of a cyprinid fish are self-sustaining despite widespread feminization of males. BMC Biol. 2014, 12, 1:1-1:13.

18. Mills, L.J.; Chichester, C. Review of evidence: Are endocrine-disrupting chemicals in the aquatic environment impacting fish populations? Sci. Total Environ. 2005, 343, 1-34.

19. Arukwe, A.; Goksøyr, A. Eggshell and egg yolk proteins in fish: Hepatic protein for the next generation: Oogenetic, population, and evolutionary implications of endocrine disruption. Comp. Hepatol. 2003, 2, 4:1-4:21.

20. Hyllner, S.J.; Oppen-Berntsen, D.O.; Helvik, J.V.; Walther, B.T.; Haux, C. Oestradiol-17 $\beta$ induces major vitelline envelope proteins in both sexes in teleosts. J. Endocrinol. 1991, 131, 229-236. 
21. Devlin, R.H.; Nagahama, Y. Sex determination and sex differentiation in fish? An overview of genetic, physiological, and environmental influences. Aquaculture 2002, 208, 191-364.

22. Piferrer, F. Endocrine sex control strategies for the feminization of teleost fish. Aquaculture 2001, 197, 229-281.

23. Diotel, N.; Le Page, Y.; Mouriec, K.; Tong, S.-K.; Pellegrini, E.; Vaillant, C.; Anglade, I.; Brion, F.; Pakdel, F.; Chung, B.-C.; et al. Aromatase in the brain of teleost fish: Expression, regulation and putative functions. Front. Neuroendocrinol. 2010, 31, 172-192.

24. Callard, G.V.; Tchoudakova, A. Evolutionary and functional significance of two CYP19 genes differentially expressed in brain and ovary of goldfish. J. Steroid Biochem. Mol. Biol. 1997, 61, 387-392.

25. Cheshenko, K.; Pakdel, F.; Segner, H.; Kah, O.; Eggen, R.I.L. Interference of endocrine disrupting chemicals with aromatase CYP19 expression or activity, and consequences for reproduction of teleost fish. Gen. Comp. Endocrinol. 2008, 155, 31-62.

26. Trant, J.M.; Gavasso, S.; Ackers, J.; Chung, B.; Place, A.R. Developmental expression of cytochrome P450 aromatase genes (CYP19a and CYP19b) in zebrafish fry (Danio rerio). J. Exp. Zool. 2001, 290, 475-483.

27. Hinfray, N.; Palluel, O.; Piccini, B.; Sanchez, W.; Aït-Aïssa, S.; Noury, P.; Gomez, E.; Geraudie, P.; Minier, C.; Brion, F.; et al. Endocrine disruption in wild populations of chub (Leuciscus cephalus) in contaminated French streams. Sci. Total Environ. 2010, 408, 2146-2154.

28. Kishida, M.; Callard, G.V. Distinct cytochrome P450 aromatase isoforms in zebrafish (Danio rerio) brain and ovary are differentially programmed and estrogen regulated during early development. Endocrinology 2001, 142, 740-750.

29. Kirby, M.F.; Allen, Y.T.; Dyer, R.A.; Feist, S.W.; Katsiadaki, I.; Matthiessen, P.; Scott, A.P.; Smith, A.; Stentiford, G.D.; Thain, J.E.; et al. Surveys of plasma vitellogenin and intersex in male flounder (Platichthys flesus) as measures of endocrine disruption by estrogenic contamination in United Kingdom estuaries: temporal trends, 1996 to 2001. Environ. Toxicol. Chem. 2004, 23, 748-758.

30. Matthiessen, P.; Allen, Y.; Bamber, S.; Craft, J.; Hurst, M.; Hutchinson, T.; Feist, S.; Katsiadaki, I.; Kirby, M.; Robinson, C.; et al. The impact of oestrogenic and androgenic contamination on marine organisms in the United Kingdom-Summary of the EDMAR programme. Endocrine Disruption in the Marine Environment. Mar. Environ. Res. 2002, 54, 645-649.

31. Allen, Y.; Matthiessen, P.; Scott, A.P.; Haworth, S.; Feist, S.; Thain, J.E. The extent of oestrogenic contamination in the UK estuarine and marine environments-further surveys of flounder. Sci. Total Environ. 1999, 233, 5-20.

32. Vethaak, A.D.; Lahr, J.; Kuiper, R.V.; Grinwis, G.C.; Rankouhi, T.R.; Giesy, J.P.; Gerritsen, A. Estrogenic effects in fish in The Netherlands: Some preliminary results. Toxicology 2002, 181-182, 147-150.

33. Vethaak, A.D.; Lahr, J.; Schrap, S.M.; Belfroid, A.C.; Rijs, G.B.; Gerritsen, A.; de Boer, J.; Bulder, A.S.; Grinwis, G.C.; Kuiper, R.V.; et al. An integrated assessment of estrogenic contamination and biological effects in the aquatic environment of The Netherlands. Chemosphere 2005, 59, 511-524. 
34. Mills, L.J.; Gutjahr-Gobell, R.E.; Horowitz, D.B.; Denslow, N.D.; Chow, M.C.; Zaroogian, G.E. Relationship between reproductive success and male plasma vitellogenin concentrations in cunner, Tautogolabrus adspersus. Environ. Health Perspect. 2003, 111, 93-100.

35. Roy, L.A.; Armstrong, J.L.; Sakamoto, K.; Steinert, S.; Perkins, E.; Lomax, D.P.; Johnson, L.L.; Schlenk, D. The relationships of biochemical endpoints to histopathology and population metrics in feral flatfish species collected near the municipal wastewater outfall of Orange County, California, USA. Environ. Toxicol. Chem. 2003, 22, 1309-1317.

36. Hashimoto, S.; Bessho, H.; Hara, A.; Nakamura, M.; Iguchi, T.; Fujita, K. Elevated serum vitellogenin levels and gonadal abnormalities in wild male flounder (Pleuronectes yokohamae) from Tokyo Bay, Japan. Mar. Environ. Res. 2000, 49, 37-53.

37. Ohkubo, N.; Mochida, K.; Adachi, S.; Hara, A.; Hotta, K.; Nakamura, Y.; Matsubara, T. Development of enzyme-linked immunosorbent assays for two forms of vitellogenin in Japanese common goby (Acanthogobius flavimanus). Gen. Comp. Endocrinol. 2003, 131, 353-364.

38. Puy-Azurmendi, E.; Ortiz-Zarragoitia, M.; Villagrasa, M.; Kuster, M.; Aragón, P.; Atienza, J.; Puchades, R.; Maquieira, A.; Domínguez, C.; López de Alda, M.; et al. Endocrine disruption in thicklip grey mullet (Chelon labrosus) from the Urdaibai Biosphere Reserve (Bay of Biscay, Southwestern Europe). Sci. Total Environ. 2013, 443, 233-244.

39. De Metrio, G.; Corriero, A.; Desantis, S.; Zubani, D.; Cirillo, F.; Deflorio, M.; Bridges, C.R.; Eicker, J.; de la Serna, J.M.; Megalofonou, P.; et al. Evidence of a high percentage of intersex in the Mediterranean swordfish (Xiphias gladius L.). Mar. Pollut. Bull. 2003, 46, 358-361.

40. Desantis, S.; Corriero, A.; Cirillo, F.; Deflorio, M.; Brill, R.; Griffiths, M.; Lopata, A.L.; de la Serna, J.M.; Bridges, C.R.; Kime, D.E.; et al. Immunohistochemical localization of CYP1A, vitellogenin and Zona radiata proteins in the liver of swordfish (Xiphias gladius L.) taken from the Mediterranean Sea, South Atlantic, South Western Indian and Central North Pacific Oceans. Aquat. Toxicol. 2005, 71, 1-12.

41. Fossi, M.C.; Casini, S.; Marsili, L.; Neri, G.; Mori, G.; Ancora, S.; Moscatelli, A.; Ausili, A.; Notarbartolo-di-Sciara, G. Biomarkers for endocrine disruptors in three species of Mediterranean large pelagic fish. Mar. Environ. Res. 2002, 54, 667-671.

42. Macías, D.; Saber, S.; Osuna, A.M.; Cruz-Castán, R.M.; Gómez-Vives, M.J.; Báez, J.C. First record of intersexuality in Euthynnus alletteratus in the Mediterranean Sea: Histological description. Mar. Biodivers. Rec. 2014, 7, e3; doi:10.1017/S1755267213001152.

43. Martin-Skilton, R.; Lavado, R.; Thibaut, R.; Minier, C.; Porte, C. Evidence of endocrine alteration in the red mullet, Mullus barbatus from the NW Mediterranean. Environ. Pollut. 2006, $141,60-68$.

44. Scott, A.P.; Katsiadaki, I.; Witthames, P.R.; Hylland, K.; Davies, I.M.; McIntosh, A.D.; Thain, J. Vitellogenin in the blood plasma of male cod (Gadus morhua): A sign of oestrogenic endocrine disruption in the open sea? Mar. Environ. Res. 2006, 61, 149-170.

45. Scott, A.P.; Sanders, M.; Stentiford, G.D.; Reese, R.A.; Katsiadaki, I. Evidence for estrogenic endocrine disruption in an offshore flatfish, the dab (Limanda limanda L.). Mar. Environ. Res. 2007, 64, 128-148.

46. Van der Oost, R.; Beyer, J.; Vermeulen, N.P.E. Fish bioaccumulation and biomarkers in environmental risk assessment: A review. Environ. Toxicol. Pharmacol. 2003, 13, 57-149. 
47. Suter, G.W. Ecological Risk Assessment; Lewis Publishers: Boca Raton, FL, USA, 1993; p. 538.

48. Ferreira, M.; Antunes, P.; Gil, O.; Vale, C.; Reis-Henriques, M.A. Organochlorine contaminants in flounder (Platichthys flesus) and mullet (Mugil cephalus) from Douro estuary, and their use as sentinel species for environmental monitoring. Aquat. Toxicol. 2004, 69, 347-357.

49. UNEP (United Nations Environmental Programme). Report of the Meeting of Experts to Review the MED POL Biomonitoring Programme; UNEP(OCA)/MED WG.132/7; UNEP: Athens, Greece, 1997.

50. Waltham, N.J.; Teasdale, P.R.; Connolly, R.M. Use of flathead mullet (Mugil cephalus) in coastal biomonitor studies: Review and recommendations for future studies. Mar. Pollut. Bull. 2013, 69, 195-205.

51. Whitfield, A.K.; Panfili, J.; Durand, J.D. A global review of the cosmopolitan flathead mullet Mugil cephalus Linnaeus 1758 (Teleostei: Mugilidae), with emphasis on the biology, genetics, ecology and fisheries aspects of this apparent species complex. Rev. Fish Biol. Fish. 2012, 22, 641-681.

52. Burgess, P.J.; Matthews, R.A. A standardized method for the in vivo maintenance of Cryptocaryon irritans (Ciliophora) using the grey mullet Chelon labrosus as an experimental host. J. Parasitol. 1994, 80, 288-292.

53. Merella, P.; Garippa, G. Metazoan parasites of grey mullets (Teleostea: Mugilidae) from the Mistras Lagoon (Sardinia, western Mediterranean). Sci. Mar. 2001, 65, 201-206.

54. Turan, C.; Caliskan, M.; Kucuktas, H. Phylogenetic relationships of nine mullet species (Mugilidae) in the Mediterranean Sea. Hydrobiologia 2005, 532, 45-51.

55. Delgado de Carvalho, C.; Marocco Corneta, C.; Sanches Uieda, V. Schooling behavior of Mugil curema (Perciformes: Mugilidae) in an estuary in southeastern Brazil. Neotrop. Ichthyol. 2007, 5, 81-83.

56. Ferreira, M.; Moradas-Ferreira, P.; Reis-Henriques, M.A. Oxidative stress biomarkers in two resident species, mullet (Mugil cephalus) and flounder (Platichthys flesus), from a polluted site in River Douro Estuary, Portugal. Aquat. Toxicol. 2005, 69, 347-357.

57. Fossi, M.C.; Mauceri, A.; Leonzio, C.; Ancora, E.; Minniti, F.; Maisano, M.; Lo Cascio, P.; Ferrando, S.; Fasulo, S. Stress factors in the gills of Liza aurata (Perciformes, Mugilidae) living in polluted environments. Ital. J. Zool. 2005, 72, 285-292.

58. Orbea, A.; Ortiz-Zarragoitia, M.; Solé, M.; Porte, C.; Cajaraville, M.P. Antioxidant enzymes and peroxisome proliferation in relation to contaminant body burdens of PAHs and PCBs in bivalve molluscs, crabs, and fish from the Urdaibai and Plentzia estuaries (Bay of Biscay). Aquat. Toxicol. 2002, 58, 75-98.

59. Maruya, K.A.; Francendese, L.; Manning, R.O. Residues of toxaphene decrease in estuarine fish after removal of contaminated sediments. Estuaries 2005, 28, 786-793.

60. Fishbase. Available online: http://www.fishbase.org (accessed on 25 March 2014).

61. Durand, J.D.; Shen, K.N.; Chen, W.J.; Jamandre, B.W.; Blel, H.; Diop, K.; Nirchio, M.; Garcia de León, F.J.; Whitfield, A.K.; Chang, C.W.; et al. Systematics of the grey mullets (Teleostei: Mugiliformes: Mugilidae): Molecular phylogenetic evidence challenges two centuries of morphology-based taxonomy. Mol. Phylogenet. Evol. 2012, 64, 73-92. 
62. Nelson, J.S. Fishes of the World, 4th ed.; John Wiley \& Sons, Inc.: Hoboken, NY, USA, 2006; p. 601.

63. McDonough, C.J.; Roumillat, W.A.; Wenner, C.A. Sexual differentiation and gonad development in striped mullet (Mugil cephalus L.) from South Carolina estuaries. Fish. Bul. 2005, 103, 601-619.

64. Rossi, A.R.; Crosettit, D.; Gornung, E.; Sola, L. Cytogenetic analysis of global populations of Mugil cephalus (striped mullet) by different staining techniques and fluorescent in situ hybridization. Heredity 1996, 76, 77-82.

65. Bruslé, J. Sexuality and biology of reproduction in grey mullets. In Aquaculture of the Grey Mullet; Oren, O.H., Ed.; Cambridge University Press: Cambridge, UK, 1981; pp. 99-154.

66. Greeley, M.S., Jr.; Calder, R.D.; Wallace, A.R. Oocyte growth and development in the striped mullet, $M$. cephalus, during seasonal ovarian recrudescence: Relationship to fecundity and size at maturity. Fish. Bull. 1987, 85, 187-200.

67. Render, J.H.; Thompson, B.A.; Allen, R.L. Reproductive development of striped mullet in Louisiana estuarine waters with notes on the applicability of reproductive assessment methods for isochronal species. Trans. Am. Fish. Soc. 1995, 124, 26-36.

68. Solomon, F.N.; Rammarine, I.W. Reproductive biology of white mullet, Mugil curema (Valeciennes) in the Southern Caribbean. Fish. Res. 2007, 88, 133-138.

69. Mićković, B.; Nikčević, M.; Hegediš, A.; Regner, S.; Gačić, Z.; Krpo-Ćetković, J. Mullet fry (Mugilidae) in coastal waters of Montenegro, their spatial distribution and migration phenology. Arch. Biol. Sci. Belgrade 2010, 62, 107-114.

70. Yashuov, A.; Berner-Samsonov, E. Contribution to the knowledge of eggs and early larval stages of mullets (Mugilidae) along the Israeli coast. Badmigeh 1970, 22, 72-89.

71. Crosetti, D.; Cataudella, S. Grey mullet culture. In World Animal Science 34B: Production of Aquatic Animals; Nash, C.E., Ed.; Elsevier B.V.: Burlington, MA, USA, 1995; pp. 271-288.

72. Koutrakis, E.T.; Kokkinakis, A.K.; Eleftheriadis, E.A.; Argyropoulou, D. Seasonal changes in distribution and abundance of the fish fauna in the two estuarine systems of Strymonikos Gulf (Macedonia, Greece). Belgian J. Zool. 2000, 130, 41-48.

73. Oliva-Paterna, F.J.; Andreu, A.; Miñano, P.A.; Verdiell, D.; Egea, A.; de Maya, J.A.; Ruiz- Navarro, A.; García-Alonso, J.; Fernández-Delgado, C.; Torralva, M. Y-O-Y fish species richness in the littoral shallows of the meso-saline coastal lagoon (Mar Menor, Mediterranean coast of the Iberian Peninsula). J. Appl. Ichthyol. 2006, 22, 235-237.

74. Simier, M.; Blanc, L.; Aliaume, C.; Diouf, P.S.; Albaret, J.J. Spatial and temporal structure of fish assemblages in an "inverse estuary”, the Sine Saloum system (Senegal). Estuar. Coast. Shelf Sci. 2004, 59, 69-86.

75. Strydom, N.A. Occurrence of larval and early juveniles fishes in the surf zone adjacent to two intermittently open estuaries, South Africa. Environ. Biol. Fish. 2003, 66, 349-359.

76. Cardona, L. Non-competitive coexistence between Mediterranean grey mullet: Evidence from seasonal changes in food availability, niche breadth and trophic overlap. J. Fish Biol. 2001, 59, 729-744.

77. Hotos, G.N.; Vlahos, N. Salinity tolerance of Mugil cephalus and Chelon labrosus (Pisces: Mugilidae) fry in experimental conditions. Aquaculture 1998, 167, 329-338. 
78. Almeida, P.R. Feeding ecology of Liza ramada (Risso, 1810) (Pisces, Mugilidae) in a south-western estuary of Portugal. Estuar. Coast. Shelf Sci. 2003, 57, 313-323.

79. Laffaille, P.; Feunteun, P.; Lefebvre, C.; Radreau, A.; Sagan, G.; Lefeuvre, J.C. Can thin-lipped mullet directly exploit the primary and detritic production of European macrotidal salt marshes? Estuar. Coast. Shelf Sci. 2002, 54, 729-736.

80. Zetina-Rejón, M.J.; Arreguín-Sánchez, F.; Chávez, E.A. Trophic structure and flows of energy in the Huizache-Caimanero lagoon complex on the Pacific coast of Mexico. Estuar. Coast. Shelf Sci. 2003, 57, 803-815.

81. Cardona, L. Habitat selection by grey mullets (Osteichthyes: Mugilidae) in Mediterranean estuaries: The role of salinity. Sci. Mar. 2006, 70, 443-455.

82. Torriceli, P.; Tongiorgi, P.; Almansi, P. Migration of grey mullet fry into the Arno river: Seasonal appearance, daily activity, and feeding rhythms. Fish. Res. 1981, 1, 219-234.

83. Oren, O.H. Aquaculture of Grey Mullets; International Biological Programme No. 26; Cambridge University Press: Cambridge, UK, 1981; p. 507.

84. Saleh, M.A. Cultured Aquatic Species Information Programme (CASIP). Mugil cephalus. In FAO Fisheries and Aquaculture Department; FAO: Rome, Italy, 2006. Available online: http://www.fao.org/fishery/culturedspecies/Mugil_cephalus/en (accessed on 10 August 2014).

85. Pastor, D.; Boix, J.; Fernández, V.; Albaigés, J. Bioaccumulation of organochlorinated contaminants in three estuarine fish species (Mullus barbatus, Mugil cephalus and Dicentrarcus labrax). Mar. Pollut. Bull. 1996, 32, 257-262.

86. Yilmaz, F. The comparison of heavy metal concentrations ( $\mathrm{Cd}, \mathrm{Cu}, \mathrm{Mn}, \mathrm{Pb}$, and $\mathrm{Zn}$ ) in tissues of three economically important fish (Anguilla anguilla, Mugil cephalus and Oreochromis niloticus) inhabiting Köycegiz Lake-Mugla (Turkey). Turk. J. Sci. Technol. 2009, 4, 7-15.

87. Ben Ameur, W.; Trabelsi, S.; El Megdiche, Y.; Ben Hassine, S.; Barhoumi, B.; Hammami, B.; Eljarrat, E.; Barceló, D.; Ridha Driss, M. Concentration of polychlorinated biphenyls and organochlorine pesticides in mullet (Mugil cephalus) and sea bass (Dicentrarchus labrax) from Bizerte Lagoon (Northern Tunisia). Chemosphere 2013, 90, 2372-2380.

88. Türkmen, A.; Türkmen, M.; Tepe, Y.; Mazlum, Y.; Oymael, S. Metal concentrations in blue crab (Callinectes sapidus) and mullet (Mugil cephalus) in Iskenderun Bay, Northern East Mediterranean, Turkey. Bull. Environ. Contam. Toxicol. 2006, 77, 186-193.

89. Ben Ameur, W.; de Lapuente, J.; El Megdiche, Y.; Barhoumi, B.; Trabelsi, S.; Camps, L.; Serret, J.; Ramos-López, D.; Gonzalez-Linares, J.; Ridha Driss, M.; et al. Oxidative stress, genotoxicity and histopathology biomarker responses in mullet (Mugil cephalus) and sea bass (Dicentrarchus labrax) liver from Bizerte Lagoon (Tunisia). Mar. Pollut. Bull. 2012, 64, 241-251.

90. Boglione, C.; Costa, C.; Giganti, M.; Cecchetti, M.; di Dato, P.; Scardi, M.; Cataudella, S. Biological monitoring of wild thicklip grey mullet (Chelon labrosus), golden grey mullet (Liza aurata), thinlip mullet (Liza ramada) and flathead mullet (Mugil cephalus) (Pisces: Mugilidae) from different Adriatic sites: Meristic counts and skeletal anomalies. Ecol. Indic. 2006, 6, 712-732.

91. An, L.; Hu, J.; Yang, M.; Zheng, B.; Wei, A.; Shang, J.; Zhao, X. CYP1A mRNA expression in redeye mullets (Liza haematocheila) from Bohai Bay, China. Mar. Pollut. Bull. 2011, 62, 718-725. 
92. Ergene, S.; Çavaş, T.; Çelik, A.; Köleli, N.; Kaya, F.; Karahan, A. Monitoring of nuclear abnormalities in peripheral erythrocytes of three fish species from the Goksu Delta (Turkey): Genotoxic damage in relation to water pollution. Ecotoxicology 2007, 16, 385-391.

93. Hafez, A.M. Mugil cephalus genome: A sensitive monitor for genotoxicity and cytotoxicity in aquatic environment. Austr. J. Basic Appl. Sci. 2009, 3, 2176-2187.

94. Aoki, J.; Nagae, M.; Takao, J.; Hara, A.; Lee, Y.D.; Yeo, I.K.; Lim, B.S.; Park, C.B.; Soyano, K. Survey of contamination of estrogenic chemicals in Japanese and Korean coastal waters using the wild grey mullet (Mugil cephalus). Sci. Total Environ. 2010, 408, 660-665.

95. Hiramatsu, N.; Matsubara, T.; Fujita, T.; Sullivan, C.V.; Hara, A. Multiple piscine vitellogenins: Biomarkers of fish exposure to estrogenic endocrine disruptors in aquatic environments. Mar. Biol. 2006, 149, 35-47.

96. Asturiano, J.F.; Romaguera, F.; Aragón, P.; Atienza, J.; Puchades, R.; Maquieira, A. Sandwich immunoassay for determination of vitellogenin in golden grey mullet (Liza aurata) serum as a field exposure biomarker. Anal. Bioanal. Chem. 2005, 381, 1152-1160.

97. Amano, H.; Fujita, T.; Hiramatsu, N.; Shimizu, M.; Sawaguchi, S.; Matsubara, T.; Kagawa, H.; Nagae, M.; Sullivan, C.V.; Hara, A. Egg yolk proteins in gray mullet (Mugil cephalus): Purification and classification of multiple lipovitellins and other vitellogenin-derived yolk proteins and molecular cloning of the parent vitellogenins genes. J. Exp. Zool. 2007, 307A, 324-341.

98. An, L.; Hu, J.; Zhang, Z.; Yang, M. Quantitative real-time RT-PCR for determination of vitellogenin mRNA in so-iuy mullet (Mugil soiuy). Anal. Bioanal. Chem. 2006, 386, 1995-2001.

99. Hao, L.-N.; Zhao, Y.-B.; Peng, H.; Huang, C.; Chen, S.-L.; Hu, J.-Y. Comparison of ER $\alpha$-mediated estrogenic binding activity between So-iuy mullet (Mugil soiuy) and medaka. China Environ. Sci. 2010, 11, 1490-1495.

100. Soyano, K.; Aoki, J.-Y.; Itashiki, Y.; Park, C.-B.; Nagae, M.; Takao, Y.; Lee, Y.-D.; Yeo, I.-K.; Zhong, J. Contaminations by endocrine disrupting chemicals in coastal waters of the East China Sea. In Coastal Environmental and E cosystem Issues of the East China Sea; Ishimatsu, A., Lie, H.-J., Eds.; TERRAPUB and Nagasaki University: Nagasaki, Japan, 2010; pp. 215-226.

101. Bizarro, C.; Ros, O.; Vallejo, A.; Prieto, A.; Etxebarria, N.; Cajaraville, M.P.; Ortiz-Zarragoitia, M. Intersex condition and molecular markers of endocrine disruption in relation with burdens of emerging pollutants in thicklip grey mullets (Chelon labrosus) from Basque estuaries (South-East Bay of Biscay). Mar. Environ. Res. 2014, 96, 19-28.

102. Diaz de Cerio, O.; Rojo-Bartolomé, I.; Bizarro, C.; Ortiz-Zarragoitia, M.; Cancio, I. $5 S$ rRNA and accompanying proteins in gonads: Powerful markers to identify sex and reproductive endocrine disruption in fish. Environ. Sci. Technol. 2012, 46, 7763-7771.

103. Bayhan, B.; Acarli, D. Hermaphrodite thinlip mullet Liza ramada (Risso, 1810) (Teleostei: Mugilidae) from Homa Lagoon (Izmir Bay-Aegean Sea). Aquac. Res. 2006, 37, 1050-1052.

104. Corsi, I.; Mariottini, M.; Sensini, C.; Lancini, N.; Focardi, S. Cytochrome P450, acetylcholinesterase and gonadal histology for evaluating contaminant exposure levels in fishes from a highly eutrophic brackish ecosystem: The Orbetello Lagoon, Italy. Mar. Pollut. Bull. 2003, 46, 203-212. 
105. Barucca, M.; Canapa, A.; Olmo, E.; Regoli, F. Analysis of vitellogenin gene induction as a valuable biomarker of estrogenic exposure in various Mediterranean fish species. Environ. Res. 2006, 101, 68-73.

106. Canapa, A.; Barucca, M.; Celeste, A.; Olmo, E.; Regoli, F. Preliminary investigations on vitellogenin m-RNA induction in some bioindicator Mediterranean fish species. Mar. Environ. Res. 2002, 54, 673-677.

107. Moe, M.A., Jr. Hermaphroditism in Mullet, Mugil cephalus Linnaeus. Q. J. Florida Acad. Sci. 1966, 29, 111-116.

108. Bizarro, C.; Aragón, P.; Maquieira, A.; Cajaraville, M.P.; Ortiz-Zarragoitia, M. Characterization by histological and molecular tools of the reproductive cycle and endocrine disruption effects on a thicklip grey mullet (Chelon labrosus) population from the South Bay of Biscay. Comp. Biochem. Physiol. Part A 2012, 163, S33.

109. Jobling, S.; Nolan, M.; Tyler, C.R.; Brighty, G.; Sumpter, J.P. Widespread sexual disruption in wild fish. Environ. Sci. Technol. 1998, 32, 2498-2506.

110. Nocillado, J.N.; Elizur, A.; Avitan, A.; Carrick, F.; Levavi-Sivan, B. Cytochrome P450 aromatase in grey mullet: cDNA and promoter isolation; brain, pituitary and ovarian expression during puberty. Mol. Cell. Endocrinol. 2007, 263, 65-78.

111. Chang, C.F.; Lan, S.C.; Pan, B.S. Feed administration of estradiol-17-beta stimulates female differentiation in juvenile grey mullet Mugil cephalus. Zool. Stud. 1995, 34, 257-264.

112. Aoki, J.-Y.; Hatsuyama, A.; Hiramatsu, N.; Soyano, K. Effects of ethynylestradiol on vitellogenin synthesis and sex differentiation in juvenile grey mullet (Mugil cephalus) persist after long-term exposure to a clean environment. Comp. Biochem. Physiol. Part C 2011, 154, 346-352.

113. Chang, C.F.; Hung, C.Y.; Chiang, M.C.; Lan, S.C. The concentrations of plasma sex steroids and gonadal aromatase during controlled sex differentiation in grey mullet, Mugil cephalus. Aquaculture 1999, 177, 37-45.

114. Meiri-Ashkenazi, I.; Solomonovich, R.; Rosenfeld, H. Long term effects of masculinizing treatments on the reproductive characteristics of grey mullet (Mugil cephalus). Indian J. Sci. Technol. 2011, 4, 300-301.

115. Baek, H.J.; Hwang, I.J.; Lee, Y.D.; Kim, H.B. Effects of nonylphenol and 3,3',4,4', 5-pentachlorobiphenil on in vitro oocyte steroidogenesis in redlip mullet, Chelon haematochelius. Anim. Cells Syst. 2011, 15, 189-196.

116. Bilbao, E.; Raingeard, D.; Diaz de Cerio, O.; Ortiz-Zarragoitia, M.; Ruiz, P.; Izagirre, U.; Orbea, A.; Marigómez, I.; Cajaraville, M.P.; Cancio, I. Effects of exposure to Prestige-like heavy fuel oil and to perfluorooctane sulfonate on conventional biomarkers and target gene transcription in the thicklip grey mullet Chelon labrosus. Aquat. Toxicol. 2010, 98, 282-296.

117. Cionna, C.; Maradonna, F.; Olivotto, I.; Pizzonia, G.; Carnevali, O. Effects of nonylphenol on juveniles and adults in the grey mullet, Liza aurata. Reprod. Toxicol. 2006, 22, 449-454.

118. Aizen, J.; Meiri, I.; Tzchori, I.; Levavi-Sivan, B.; Rosenfeld, H. Enhancing spawning in the grey mullet (Mugil cephalus) by removal of dopaminergic inhibition. Gen. Comp. Endocrinol. 2005, 142, 212-221. 
119. Nakamura, S.; Kobayashi, K.; Nishimura, T.; Higashijima, S.; Tanaka, M. Identification of germline stem cells in the ovary of the teleost medaka. Science 2010, 328, 1561-1563.

120. Yoshizaki, G.; Ichikawa, M.; Hayashi, M.; Iwasaki, Y.; Miwa, M.; Shikina, S.; Okutsu, T. Sexual plasticity of ovarian germ cells in rainbow trout. Development 2010, 137, 1227-1230.

121. Yoshizaki, G.; Okutsu, T.; Morita, T.; Terasawa, M.; Yazawa, R.; Takeuchi, Y. Biological characteristics of fish germ cells and their application to developmental biotechnology. Reprod. Domest. Anim. 2012, 47, 187-192.

122. Selman, K.; Wallace, R.A.; Sarka, A.; Qi, X. Stages of oocyte development in the zebrafish Brachydanio rerio. J. Morphol. 1993, 218, 203-224.

123. Murua, H.; Kraus, G.; Saborido-Rey, F.; Witthames, P.R.; Thorsen, A.; Junquera, S. Procedures to estimate fecundity of marine fish species in relation to their reproductive strategy. J. Northw. Atl. Fish. Sci. 2003, 33, 33-54.

124. Lubzens, E.; Young, G.; Bobe, J.; Cerdá, J. Oogenesis in teleosts: How fish eggs are formed. Gen. Comp. Endocrinol. 2010, 16, 367-389.

125. Mazabraud, A.; Wegnez, M.; Denis, H. Biochemical research on oogenesis: RNA accumulation in the oocytes of teleosts. Dev. Biol. 1975, 44, 326-332.

126. Denis, H.; Wegnez, M. Biochemical research on oogenesis: Oocytes and liver cells of the teleost fish Tinca tinca contain different kinds of 5S RNA. Dev. Biol. 1977, 59, 228-236.

127. Mittelholzer, C.; Andersson, E.; Consten, D.; Hirai, T.; Nagahama, Y.; Norberg, B. 20 beta-hydroxysteroid dehydrogenase and CYP19A1 are differentially expressed during maturation in Atlantic cod (Gadus morhua). J. Mol. Endocrinol. 2007, 39, 319-328.

128. Kroupova, H.; Trubiroha, A.; Wuertz, S.; Kloas, W. Stage-dependent differences in RNA composition and content affect the outcome of expression profiling in roach (Rutilus rutilus) ovary. Comp. Biochem. Physiol. Part A 2011, 159, 141-149.

129. Penberthy, W.T.; Griffin, D.; Hall, R.K.; Taylor, W.L. The Xenopus B2 factor involved in TFIIIA gene regulation is closely related to Sp1 and interacts in a complex with USF. Gene 2003, 305, 205-215.

130. Thiry, M.; Poncin, P. Morphological changes of the nucleolus during oogenesis in oviparous teleost fish, Barbus barbus (L.). J. Struct. Biol. 2005, 152, 1-13.

131. Campo, D.; Machado-Schiaffino, G.; Horreo, J.L.; Garcia-Vazquez, E. Molecular organization and evolution of 5S rDNA in the genus Merluccius and their phylogenetic implications. J. Mol. Evol. 2009, 68, 208-216.

132. Gornung, E.; Colangelo, P.; Annesi, F. 5S ribosomal RNA genes in six species of Mediterranean grey mullets: Genomic organization and phylogenetic inference. Genome 2007, 50, 787-795.

133. Szymański, M.; Barciszewska, M.Z.; Erdmann, V.A.; Barciszewski, J. 5S rRNA: Structure and interactions. Biochem. J. 2003, 371, 641-651.

134. Allison, L.A.; North, M.T.; Neville, L.A. Differential binding of oocyte-type and somatic-type 5S rRNA to TFIIIA and ribosomal protein L5 in Xenopus oocytes: Specialization for storage versus mobilization. Dev. Biol. 1995, 168, 284-295.

135. Martins, C.; Galetti, P.M., Jr. Two 5S rDNA arrays in neotropical fish species: Is it a general rule for fishes? Genetica 2001, 111, 439-446. 
136. Pinhal, D.; Yoshimura, T.S.; Araki, C.S.; Martins, C. The 5S rDNA family evolves through concerted and birth-and-death evolution in fish genomes: An example from freshwater stingrays. BMC Evol. Biol. 2011, 11, 151:1-151:14.

137. He, W.; Qin, Q.; Liu, S.; Li, T.; Wang, J.; Xiao, J.; Xie, L.; Zhang, C.; Liu, Y. Organization and variation analysis of 5S rDNA in different ploidy-level hybrids of red crucian carp $\times$ topmouth culter. PLoS One 2012, 7, e38976:1-e38976:12.

138. Sreenivasan, R.; Cai, M.; Bartfai, R.; Wang, X.; Christoffels, A.; Orban, L. Transcriptomic analyses reveal novel genes with sexually dimorphic expression in the zebrafish gonad and brain. PLoS One 2008, 3, e1791:1-e1791:16.

139. Layat, E.; Probst, A.V.; Tourmente, S. Structure, function and regulation of Transcription Factor IIIA: From Xenopus to Arabidopsis. Biochim. Biophys. Acta 2013, 1829, 274-282.

140. Ogilvie, M.K.; Hanas, J.S. Molecular biology of vertebrate transcription factor IIIA: Cloning and characterization of TFIIIA from channel catfish oocytes. Gene 1997, 203, 103-112.

141. Kanamori, A. Systematic identification of genes expressed during early oogenesis in medaka. Mol. Reprod. Dev. 2000, 55, 31-36.

142. Kinoshita, M.; Okamoto, G.; Hirata, T.; Shinomiya, A.; Kobayashi, T.; Kubo, Y.; Hori, H.; Kanamori, A. Transgenic medaka enables easy oocytes detection in live fish. Mol. Reprod. Dev. 2009, 76, 202-207.

143. Gen, K.; Yamaguchi, S.; Okuzawa, K.; Kagawa, H.; Alam, M.S. Novel expression of importin alpha homologue in marine teleost, Pagrus major. Comp. Biochem. Physiol. Part B 2008, 151, 420-427.

144. Holt, J.E.; Ly-Huynh, J.D.; Efthymiadis, A.; Hime, G.R.; Loveland, K.L.; Jans, D.A. Regulation of nuclear import during differentiation; the IMP alpha gene family and spermatogenesis. Curr. Genomics 2007, 8, 323-334.

145. Wischnewski, J.; Rudt, F.; Pieler, T. Signals and receptors for the nuclear transport of TFIIIA in Xenopus oocytes. Eur. J. Cell Biol. 2004, 83, 55-66.

146. DeJong, J. Basic mechanisms for the control of germ cell gene expression. Gene 2006, 366, 39-50.

147. Griffin, D.; Penberthy, W.T.; Lum, H.; Stein, R.W.; Taylor, W.L. Isolation of the B3 transcription factor of the Xenopus TFIIIA gene. Gene 2003, 313, 179-188.

(C) 2014 by the authors; licensee MDPI, Basel, Switzerland. This article is an open access article distributed under the terms and conditions of the Creative Commons Attribution license (http://creativecommons.org/licenses/by/3.0/). 